\title{
Managing the drug treatment of rheumatoid arthritis
}

\section{SUMMARY}

Rheumatoid arthritis is an inflammatory condition affecting synovial joints. Without treatment, the underlying inflammatory process leads to joint destruction, pain, deformity, disability and accelerated cardiovascular disease.

Disease-modifying antirheumatic drugs will attenuate the inflammation. Their benefits are seen at all stages of the disease, however the best outcomes are achieved when they are used shortly after the onset. Patients with suspected rheumatoid arthritis should be referred promptly.

Disease-modifying antirheumatic drugs are often used in combination and can have serious adverse effects. Their safe use requires ongoing monitoring to identify potential adverse events.

The risk of infection is increased and vaccination is best given before starting disease-modifying antirheumatic drugs.

\section{Introduction}

Rheumatoid arthritis is a chronic autoimmune condition that classically presents as a symmetrical polyarthritis of proximal small synovial joints. It has a prevalence of $0.46 \%$ in the Australasian region, and affects women more frequently than men. ${ }^{1}$ The onset is usually between 35 and 60 years, however the majority of the disease burden in Australia is in people over 65 years. $^{2}$

The cause of rheumatoid arthritis remains unknown, although our understanding of the pathological processes has advanced greatly in the last 20 years. Many pro-inflammatory cytokines are involved and some of these are therapeutic targets for the development of new drugs. ${ }^{3}$

Optimal management of rheumatoid arthritis requires an understanding of the therapeutic goals, the options available to attain them and the associated potential complications. Drugs are only one part of the management of the patient.

\section{The significance of inflammation}

The cytokine milieu in rheumatoid arthritis influences a multitude of physiological processes. These include promoting the influx of immune effector cells into the joint synovium, and activation of osteoclasts, chondrocytes and fibroblasts. ${ }^{3}$ There is a positive feedback loop that reinforces the inflammatory process. Unabated, this process results in joint pain and destruction, ultimately causing deformity and disability.
Chronic inflammation also contributes to an increased risk of myocardial infarction, stroke and death. A Canadian population-based prospective cohort study reported an absolute increase in cardiovascular events of 5.7 per 1000 person-years (95\% confidence interval 4.9-6.4) in patients with rheumatoid arthritis compared to those without. ${ }^{4}$ The use of disease-modifying antirheumatic drugs (DMARDs) to attenuate the inflammatory process has been shown to prevent joint erosions and reduce pain, cardiovascular morbidity and mortality. ${ }^{3,5}$

\section{Nomenclature}

The development of targeted monoclonal antibodies and small-molecule kinase inhibitors has widened the therapeutic options in rheumatoid arthritis. Each drug has a proven ability to modify the disease process to varying extents. However, the increase in drugs has thwarted our simple terminology of DMARDs, as the term no longer refers solely to synthetic chemical entities. A new nomenclature has been proposed ${ }^{6}$ and applied to the drugs registered in Australia for the treatment of rheumatoid arthritis (see Box).

A systematic review and meta-analysis found that corticosteroids reduce demonstrated radiographic erosions. ${ }^{7}$ While this effect defines corticosteroids as DMARDs, their toxicity profile makes routine long-term use undesirable. Other infrequently used DMARD therapies include azathioprine, ciclosporine and gold salts.

\section{Tom D Wilsdon}

Clinical pharmacology registrar ${ }^{r}$

Associate lecturer ${ }^{2}$

\section{Catherine L Hill}

Consultant

rheumatologist ${ }^{3,4}$

Clinical professor ${ }^{5}$

' Department of Clinical

Pharmacology

Flinders Medical Centre

2 School of Medicine

Nursing and Health

Sciences

Flinders University

${ }^{3}$ Department of

Rheumatology

The Queen Elizabeth Hospital

${ }^{4}$ Department of

Rheumatology

Royal Adelaide Hospital

5 School of Medicine

Faculty of Health Sciences University of Adelaide Adelaide

\section{Keywords}

disease-modifying antirheumatic drugs (DMARDs), immunosuppression, rheumatoid arthritis

Aust Prescr 2017:40:51-8 http://dx.doi.org/10.18773/ austprescr.2017.012 


\section{Box Disease-modifying antirheumatic drugs}

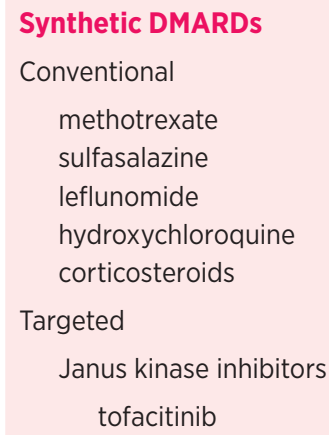

\section{Biologic DMARDs}

Tumour necrosis factor antagonists

adalimumab

golimumab

certolizumab pegol

infliximab*

etanercept

IL-1 receptor antagonist

anakinra

IL-6 receptor antagonist

tocilizumab

Anti-CD20 monoclonal antibody

rituximab

CTLA-4-Ig fusion protein

abatacept

DMARDs disease-modifying anti-rheumatic drugs

IL interleukin

CTLA cytotoxic lymphocyte-associated antigen

* also available as a biosimilar

\section{The importance of early treatment}

Remission is unlikely to occur without intervention. ${ }^{8}$ Bone erosions are detectable in $25 \%$ of people within three months of onset ${ }^{9}$ and in $70 \%$ by three years. ${ }^{10}$ Delaying treatment beyond three months causes more joint destruction and a higher chance of requiring persistent DMARDs to maintain remission." Early DMARD therapy during this 'window of opportunity' (that is within three months of onset) will more readily induce remission and delay progression. ${ }^{9}$

\section{Methotrexate monotherapy}

Methotrexate is the backbone of rheumatoid arthritis treatment. Monotherapy consistently reduces radiographic progression and improves quality of life..$^{12}$ Approximately $40 \%$ of patients will respond to monotherapy. ${ }^{13}$ Limited comparative data suggest that other conventional DMARD monotherapies are as effective as methotrexate. ${ }^{14}$ However, its demonstrated long-term benefits, cost, acceptable safety profile and synergy with other DMARDs make methotrexate the recommended first choice for monotherapy in the guidelines of the American College of Rheumatology (ACR) and the European League Against Rheumatism (EULAR). ${ }^{15,16}$

\section{Combination therapies}

Combining DMARDs is frequently used as a first-line strategy, particularly for those with poor prognostic factors. A systematic review and network metaanalysis compared methotrexate monotherapy to methotrexate in combination with other DMARDs for patients with rheumatoid arthritis who were treatmentnaïve or had an inadequate response to methotrexate alone. ${ }^{13}$ The combination of methotrexate with sulfasalazine and hydroxychloroquine, so called 'triple therapy', has greater efficacy than monotherapy in both early rheumatoid arthritis and non-responders, but higher toxicity. ${ }^{13}$ Combining methotrexate with biologic DMARDs has also demonstrated superior outcomes compared to methotrexate monotherapy in those with an inadequate response. ${ }^{13}$

The optimal combination of DMARDs and timing of combination therapy is debated. Unless methotrexate is poorly tolerated it should always be continued when starting other DMARDs.

\section{Choosing the right treatment}

The choice of treatment for a patient is influenced by the duration and severity of disease, previous treatments and regulatory restrictions. There are also patient-specific factors such as comorbidities, patient preference, family planning, and financial and social circumstances.

\section{Pre-treatment evaluation}

Before starting DMARDs, all patients should have baseline blood tests including full blood examination, serum creatinine and liver enzymes. Abnormalities may alter the choice of therapy and dosing (e.g. methotrexate is renally excreted). All patients should be screened for hepatitis B virus, hepatitis $C$ virus and tuberculosis as there is a risk of reactivation of latent infections or worsening of active infection. Other important considerations include congestive heart failure, malignancy, lymphoproliferative disease, multiple sclerosis, chronic obstructive pulmonary disease, bronchiectasis and interstitial lung disease. Further evaluation is required before treatment.

\section{Pregnancy, contraception and lactation}

The management of rheumatoid arthritis before, during and after pregnancy can be challenging. Although many women will have an improvement in 
disease activity during pregnancy, remission is rare. ${ }^{17}$ Poor pregnancy outcomes occur more commonly with high disease activity and include miscarriage, prematurity and pre-eclampsia. ${ }^{17}$ With the exception of sulfasalazine and hydroxychloroquine, all DMARDs are considered either unsafe or of uncertain safety during pregnancy. ${ }^{18}$ Counselling on effective methods of contraception is essential to prevent unplanned pregnancy while taking teratogenic drugs. ${ }^{17}$ Planned pregnancy is preferable and allows time for appropriate treatment changes to be made while optimising disease control. Certain DMARDs (e.g. leflunomide, methotrexate) must be stopped at least 3-6 months before conception. ${ }^{18}$

During lactation the immunosuppressive effects of some DMARDs may affect the infant because of drug excretion into breast milk. Information on drugs and lactation can be found at the United States National Institute of Health Lactmed website (https://toxnet.nlm.nih.gov/newtoxnet/lactmed.htm) or via local medicines information services.

\section{Treating to target}

The aim for every patient is to achieve a target of remission or low disease activity, as this leads to better outcomes. ${ }^{16}$ Disease activity is quantified by validated tools, such as the disease activity score based on a 28-joint count (DAS28), the clinical disease activity index (CDAI) and the simplified disease activity index (SDAI). ${ }^{16} \mathrm{~A}$ score is calculated from patient-reported pain and function, serum markers of inflammation (e.g. C-reactive protein or erythrocyte sedimentation rate) and physical joint examination. A score of moderate to high disease activity is an indication for more intense therapy with combination DMARDs until the target score (or lower) is achieved. While the optimal scores for defining low disease activity and remission continue to be refined, the treat-to-target approach is recommended by the ACR and EULAR guidelines. ${ }^{15,16}$ These provide a practical summary of evidence-based treatment algorithms, although they do not completely reflect the Australian regulatory restrictions. The Australian restrictions can be reviewed at the Australian Government Department of Human Services website (www. humanservices.gov.au/health-professionals/enablers/ rheumatoid-arthritis).

\section{Monitoring}

Monitoring treatment with DMARDs is important to ensure their safe and effective use. The potential adverse effects of methotrexate include mouth ulcers, gastrointestinal discomfort, hepatotoxicity, myelosuppression, reversible alopecia and pneumonitis. The development of adverse drug reactions should prompt review for incorrect dosing, drug interactions or new renal impairment. Supplementation with folic acid can improve the gastrointestinal symptoms and reduce the risk of liver function abnormalities. ${ }^{19}$ Although an optimal folic acid regimen has not been identified, 5-10 mg orally once a week, preferably not on the same day as methotrexate, is generally recommended.

Details regarding adverse drug reactions and the monitoring of DMARDs can be found in the Table, 20,21 or in previous Australian Prescriber articles. ${ }^{22-27}$ Patient medicine information handouts are also available from the Australian Rheumatology Association website (www.rheumatology.org.au).

\section{Infection}

Patients with rheumatoid arthritis have an increased incidence of infection compared to the general population, in particular those with higher disease severity, corticosteroid use and other comorbidities. ${ }^{28}$ Combination DMARD regimens, especially those that include a biologic drug, are associated with a markedly increased risk of serious infections. ${ }^{29}$ This risk is highest in the first six months of therapy. ${ }^{29}$ These infections are of concern, in particular reactivation of tuberculosis. ${ }^{30}$ The risk of reactivation of latent tuberculosis is high with DMARD use, particularly with biologic DMARDs and tofacitinib. ${ }^{15}$ Vigilance for infection is important, as its signs and symptoms may be atypical in immunosuppressed patients. In particular the febrile response may be blunted due to cytokine blockade. Patients should be advised to seek medical attention if they have localising symptoms of infection, an unexplained illness or a fever.

The management of minor infection requires ongoing clinical review until it resolves, with early consideration of antimicrobial therapy. Herpes zoster is more common in people taking tofacitinib and biologic drugs and may have multi-dermatomal presentations. ${ }^{31}$ Early antiviral treatment is required. The continuation of DMARDs with recurrent minor infections should be discussed with the treating rheumatologist.

Serious infections requiring hospitalisation or intravenous antibiotics usually lead to the discontinuation of most DMARDs, especially tumour necrosis factor antagonists. Long-term corticosteroids, if part of the current therapy, should be continued and possibly increased during infection due to the likelihood of adrenal suppression and the risk of an Addisonian crisis if they are stopped. Resumption of other DMARDs may be 
considered after recovery, but must be done with informed consent and close monitoring. Repeated infections, irrespective of severity, may also lead to DMARD discontinuation.

\section{Disease flares}

The definition of a 'flare' in rheumatoid arthritis poses a challenge, as patient and physician reports of flare do not always correlate with an increase in disease activity. ${ }^{32}$ Flares defined by increased disease activity are associated with increased pain, functional deterioration and radiographic progression. ${ }^{33}$ These flares often occur when the dose of DMARD is reduced.

Objective assessment of disease activity is essential to determine if treatment intensification is required. This should include a joint assessment, a patientand physician-reported disease severity measure, and measures of inflammation such as C-reactive protein or erythrocyte sedimentation rate. Increases in disease activity should trigger an urgent review by a rheumatologist.

Pain may be managed with paracetamol or nonsteroidal anti-inflammatory drugs (NSAIDs). Opioid analgesia may cause adverse drug reactions without additional benefit and is best avoided..$^{34}$

Glucocorticoids may be considered for disease flares. They are given either orally at low dose (e.g. prednisolone 10-15 mg daily), intramuscularly or intra-articularly. Intramuscular injections (e.g. methylprednisolone acetate) have the benefit of sustained activity without the inconvenience of daily oral dosing or a requirement for tapering the dose.

\section{Vaccination}

When indicated, vaccination for pneumococcus, influenza, hepatitis $A$ and $B$ and human papillomavirus is recommended irrespective of DMARD choice. ${ }^{15}$ Live vaccines should be avoided in people taking DMARDs, although varicella zoster may be considered in those who are not on biologic DMARDs. ${ }^{15}$ Vaccines may be given any time during therapy, however the best time is before treatment as DMARDs may attenuate the immune response. We recommend consulting the Australian Immunisation Handbook for further details. ${ }^{35}$

\section{Complementary medicines}

Despite widespread use of complementary medicines there remains a lack of evidence of their benefit. No complementary medicines have demonstrated disease-modifying effects. Meta-analyses of the published data suggest that omega-3 polyunsaturated fatty acids are effective at improving pain and reducing NSAID use. The optimal dose is yet to be determined (reported range 1.7-9.6 g daily). ${ }^{36}$ Evening primrose oil, borage seed oil, Tripterygium wilfordii Hook F (thunder god vine) and blackcurrant seed oil may improve some symptoms of rheumatoid arthritis. ${ }^{36,37}$ Adverse effects have been reported, making the harm-benefit profile unfavourable. ${ }^{37}$

\section{The advent of biosimilars}

A biosimilar is a biologic drug that is similar, but not identical, to a registered original biologic drug. The differences may theoretically result in altered efficacy and increased immunogenicity, therefore strict regulation is essential. The Australian Therapeutic Goods Administration requires multiple criteria to be fulfilled before a biosimilar can be registered. ${ }^{38}$ Considering the current expense of biologic drugs for rheumatoid arthritis in Australia, a cheaper and effective biosimilar is an attractive option. Even if it is deemed to be equivalent to the original product, the safety and efficacy of switching between products is uncertain.

\section{Conclusion}

The advances in rheumatoid arthritis therapy over the last 20 years have markedly changed the way the disease is managed and have improved outcomes. Understanding the therapeutic goals and the options available to achieve them, pretreatment evaluation, and the ongoing monitoring for complications of the disease and its treatment, will ensure the best outcomes for patients. Further advances in biotechnology are likely to lead to even more changes in the therapeutic landscape of rheumatoid arthritis. $\varangle$

Tom Wilsdon attended Editorial Executive Committee meetings as the clinical pharmacology registrar for Australian Prescriber in 2016. He is a member of the South Australian Formulary Committee.

Catherine Hill is currently the Honorary Secretary of the Australian Rheumatology Association, Chair of the South Australian Medicines Evaluation Panel, member of the South Australian Medicines Advisory Committee, member of the Drug Utilisation Subcommittee of the Pharmaceutical Benefits Advisory Committee, and previous member of the Australian Committee for Prescription Medicine for the Therapeutic Goods Administration. She has been the principal local investigator for drug trials with GSK, Servier, Axsome and Merck, and has been involved in drug trials by $U C B$, Roche and Abbvie. Catherine has received airfares and accommodation costs from Abbvie and Bristol-Myers Squibb to attend meetings internationally and interstate.

Acknowledgements: The authors would like to thank Bethan Richards for reviewing the manuscript and her advice on important monitoring issues and adverse drug reactions. 


\section{Table Disease-modifying antirheumatic drugs and monitoring in rheumatoid arthritis}

\begin{tabular}{|c|c|c|c|}
\hline Drug & Adverse drug reaction & Monitoring & Action \\
\hline \multirow{4}{*}{ For all DMARDs } & Myelosuppression & Routine unless otherwise specified: & \multirow{4}{*}{$\begin{array}{l}\text { Abnormalities in blood monitoring may lead to dose } \\
\text { adjustments, treatment interruption or cessation. }\end{array}$} \\
\hline & Hepatotoxicity & $\begin{array}{l}\text { FBE, EUC, LFTs at baseline, } 2-4 \text { weekly } \\
\text { for 3-6 months and every } 6-12 \text { weeks } \\
\text { thereafter. This regimen is influenced by } \\
\text { comorbidities and changes to therapy. }\end{array}$ & \\
\hline & Malignancy & $\begin{array}{l}\text { Age-related cancer screening programs } \\
\text { and self-reported symptoms }\end{array}$ & \\
\hline & Infection & $\begin{array}{l}\text { Self-reported fever ( }>38^{\circ} \mathrm{C} \text { ), localising } \\
\text { symptoms or unexplained illness. Fever } \\
\text { may not always be present due to } \\
\text { DMARD-induced alterations in cytokine } \\
\text { profile. Maintain a high index of suspicion, } \\
\text { particularly for reactivation of latent } \\
\text { tuberculosis or hepatitis B infection. }\end{array}$ & \\
\hline \multirow{7}{*}{ Methotrexate } & Alopecia & Self-reported hair loss & Usually reversible after stopping drug \\
\hline & Mouth ulcers & $\begin{array}{l}\text { Self-reported mouth ulcers } \\
\text { Inspection of oral mucosa }\end{array}$ & $\begin{array}{l}\text { Folic acid supplementation (not on day of } \\
\text { methotrexate) }\end{array}$ \\
\hline & Pneumonitis & Symptoms of cough or dyspnoea & CXR, PFTs and urgent specialist review \\
\hline & & Routine respiratory examination & \\
\hline & Abnormal LFTs & LFTs as per routine for all DMARDs & Continue folic acid supplementation. \\
\hline & Cirrhosis & & $\begin{array}{l}\text { If AST or ALT < } 2 \text { x ULN, repeat LFTs in a month. } \\
\text { If normalising, continue. If persistent elevation, } \\
\text { reduce dose. }\end{array}$ \\
\hline & & & $\begin{array}{l}\text { If AST or ALT >2 x ULN, interrupt treatment and } \\
\text { discuss with rheumatologist. }\end{array}$ \\
\hline \multirow{3}{*}{ Sulfasalazine } & Haemolytic anaemia & Symptoms of anaemia & Stop treatment and seek specialist advice. \\
\hline & Abnormal LFTs & LFTs as per routine for all DMARDs & $\begin{array}{l}\text { If AST or ALT < } 2 \text { x ULN, repeat LFTs in a month. } \\
\text { If normalising, continue. If persistent elevation, } \\
\text { reduce dose. }\end{array}$ \\
\hline & & & $\begin{array}{l}\text { If AST or ALT }>2 \times \text { ULN, interrupt treatment and } \\
\text { discuss with rheumatologist. }\end{array}$ \\
\hline \multirow{9}{*}{ Corticosteroids } & $\begin{array}{l}\text { Adrenal suppression } \\
\text { (more likely with } \\
\text { courses }>3 \text { weeks and } \\
\text { prednisolone doses } \\
\geq 7.5 \mathrm{mg} \text { ) }\end{array}$ & No specific monitoring required & $\begin{array}{l}\text { Do not stop abruptly. Consider increasing the dose } \\
\text { during intercurrent acute illness. }\end{array}$ \\
\hline & Diabetes & Blood glucose and HbAlc monitoring & $\begin{array}{l}\text { If continued use is necessary, consider escalation of } \\
\text { hypoglycaemic treatment. }\end{array}$ \\
\hline & Hypertension & Blood pressure checks each visit & $\begin{array}{l}\text { If continued use is necessary, consider } \\
\text { antihypertensive drugs. }\end{array}$ \\
\hline & $\begin{array}{l}\text { Osteoporosis (when used } \\
\text { at doses of prednisolone } \\
\geq 7.5 \mathrm{mg} \text { for } \geq 3 \text { months) }\end{array}$ & $\begin{array}{l}\text { Bone mineral density assessment at } \\
\text { baseline, repeat at } 3 \text { months } \\
\text { Self-reported skeletal pain suggesting } \\
\text { fracture }\end{array}$ & $\begin{array}{l}\text { If continued use is necessary, strongly consider } \\
\text { starting a bisphosphonate. }\end{array}$ \\
\hline & Psychosis & Vigilance for new or worsened mental & Cease, or use the lowest possible dose. Seek specialist \\
\hline & Mania & health or sleep disturbance & advice. Discuss with rheumatologist. \\
\hline & Delirium & & \\
\hline & Depression & & \\
\hline & Insomnia & & \\
\hline
\end{tabular}




\section{Table Disease-modifying antirheumatic drugs and monitoring in rheumatoid arthritis (continued)}

\begin{tabular}{|c|c|c|c|}
\hline Drug & Adverse drug reaction & Monitoring & Action \\
\hline \multirow{5}{*}{ Hydroxychloroquine } & Photosensitivity & Self-reported sensitivity & Sun protection strategies \\
\hline & Haemolytic anaemia & Symptoms of anaemia & Stop treatment and seek specialist advice. \\
\hline & $\begin{array}{l}\text { Blue-grey skin } \\
\text { discolouration }\end{array}$ & $\begin{array}{l}\text { Self-reported skin discolouration and } \\
\text { examination of sun-exposed sites }\end{array}$ & $\begin{array}{l}\text { Stop treatment immediately and seek specialist advice. } \\
\text { Sun protection strategies }\end{array}$ \\
\hline & $\begin{array}{l}\text { Corneal deposits } \\
\text { Retinal toxicity }\end{array}$ & $\begin{array}{l}\text { Baseline ophthalmological assessment, } \\
\text { then repeat at } 5 \text { years with annual review } \\
\text { thereafter if therapy ongoing. }{ }^{20} \text { Annual } \\
\text { review is recommended from initiation of } \\
\text { therapy in high-risk patients (age }>70 \text { years, } \\
\text { macular disease, renal disease, liver disease, } \\
\text { higher than recommended dose). }{ }^{20}\end{array}$ & Stop drug and seek specialist advice. \\
\hline & & Self-reported visual disturbance & \\
\hline \multirow{9}{*}{ Leflunomide } & Alopecia & Self-reported hair loss & Usually reversible. Reduce dose or stop drug. \\
\hline & Hypertension & Blood pressure assessment on each visit & Reduce dose and/or add antihypertensive. \\
\hline & Pneumonitis & Symptoms of cough or dyspnoea & CXR, PFTs and seek specialist review. \\
\hline & & Routine respiratory examination & \\
\hline & Peripheral neuropathy & Self-reported paraesthesia or weakness & $\begin{array}{l}\text { Stop drug, consider NCS and EMG if not resolving, } \\
\text { seek specialist advice. }\end{array}$ \\
\hline & Hepatotoxicity & $\begin{array}{l}\text { LFTs every } 2-4 \text { weeks for } 3 \text { months, then } \\
\text { every } 3 \text { months ongoing }\end{array}$ & $\begin{array}{l}\text { If AST or ALT }<2 \times U L N \text {, continue and repeat LFTs in } \\
\text { a month. }\end{array}$ \\
\hline & & & $\begin{array}{l}\text { If AST or ALT } 2-3 \times \text { ULN, reduce dose and repeat LFTs } \\
\text { in } 2-4 \text { weeks. Continue if normalising. If persistent } \\
\text { elevation, discuss with rheumatologist. }\end{array}$ \\
\hline & & & $\begin{array}{l}\text { If AST or ALT }>3 \times \text { ULN, stop drug and repeat LFTs in } \\
2-4 \text { weeks. If elevated, discontinue, consider washout } \\
\text { and discuss with rheumatologist. }\end{array}$ \\
\hline & & & $\begin{array}{l}\text { Note: For any severe reactions to leflunomide consider } \\
\text { cholestyramine washout ( } 8 \mathrm{~g} 3 \text { times a day for } 11 \text { days) }\end{array}$ \\
\hline \multirow{5}{*}{ Tofacitinib } & Abnormal LFTs & $\begin{array}{l}\text { LFT frequency determined by other } \\
\text { DMARDs used }\end{array}$ & $\begin{array}{l}\text { If AST or ALT 1-2 x ULN, seek specialist advice. } \\
\text { If AST or ALT >2 } \times \text { ULN, seek urgent advice. }\end{array}$ \\
\hline & Myelosuppression & FBE after 3-4 weeks, then every 3 months & Seek specialist advice, stop drug if severe. \\
\hline & Dyslipidaemia & $\begin{array}{l}\text { Lipid profile } 8 \text { weeks after starting and } \\
\text { then guided by results }\end{array}$ & $\begin{array}{l}\text { Modify lifestyle and diet, consider lipid-lowering } \\
\text { therapy. }\end{array}$ \\
\hline & Reactivated tuberculosis & $\begin{array}{l}\text { Ideally detected pre-treatment, but may } \\
\text { present during treatment as pulmonary or } \\
\text { disseminated disease }\end{array}$ & Stop treatment immediately and seek specialist advice. \\
\hline & Herpes zoster & Patient-reported rash or pain & $\begin{array}{l}\text { Start antiviral treatment within } 72 \text { hours of rash onset. } \\
\text { If recurrent, discuss with rheumatologist. }\end{array}$ \\
\hline \multirow{4}{*}{ Abatacept } & COPD exacerbation & Symptoms of COPD exacerbation & Treat exacerbation and discuss with rheumatologist. \\
\hline & Hypertension & Blood pressure & Modify lifestyle, consider antihypertensive. \\
\hline & Injection site reactions & Visualisation of injection site & $\begin{array}{l}\text { Rotation of injection sites, antihistamines, topical cold } \\
\text { packs, topical corticosteroids }\end{array}$ \\
\hline & Anaphylaxis & - & See Australian Prescriber wallchart ${ }^{21}$ \\
\hline \multirow{3}{*}{ Rituximab } & Infusion reactions & - & Stop or slow the rate of infusion, treat symptoms. \\
\hline & Anaphylaxis & - & See Australian Prescriber wallchart ${ }^{21}$ \\
\hline & Myelosuppression & FBE before each treatment & If severe, delay treatment. \\
\hline
\end{tabular}




\section{Table Disease-modifying antirheumatic drugs and monitoring in rheumatoid arthritis (continued)}

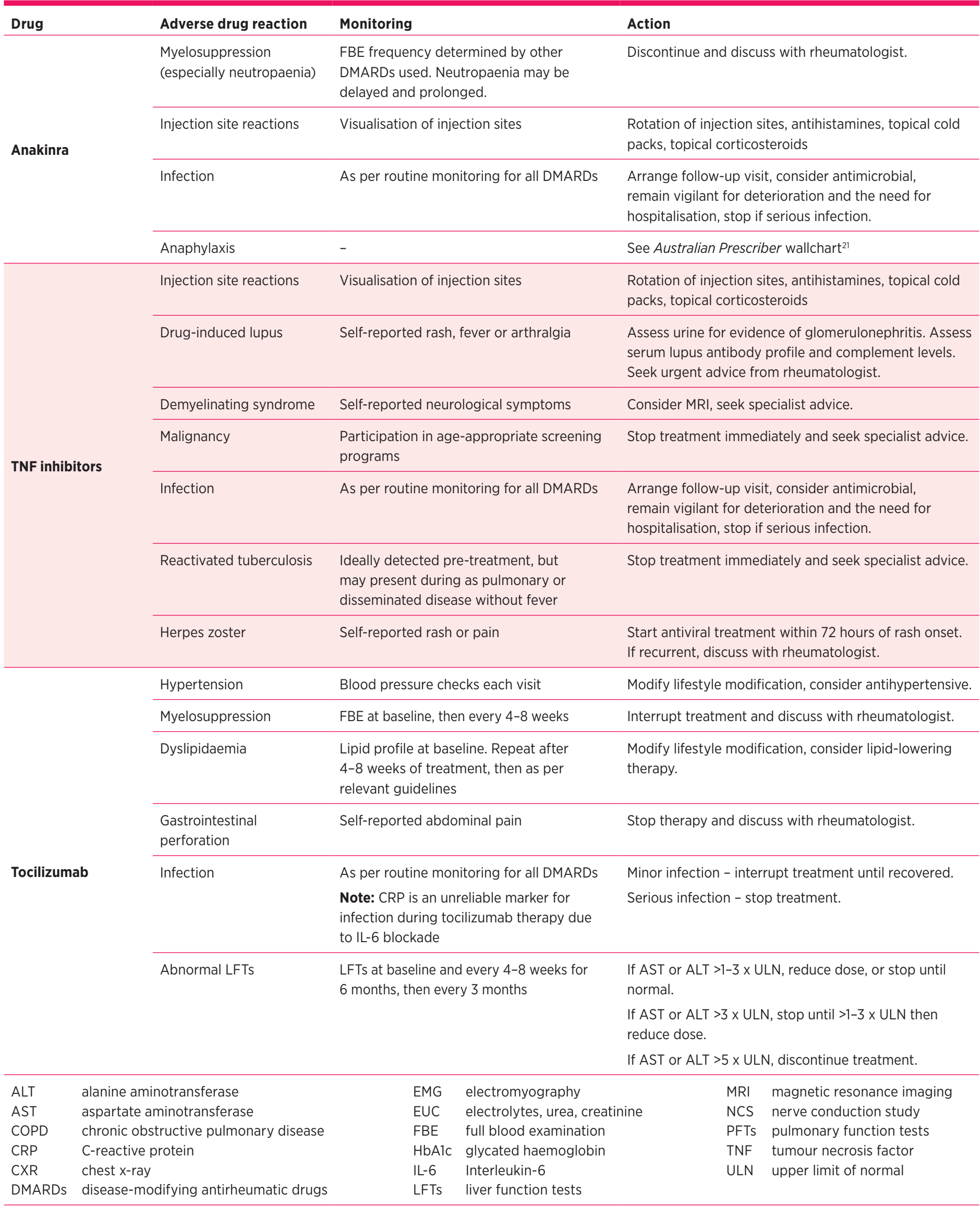


1. Cross M, Smith E, Hoy D, Carmona L, Wolfe F, Vos T, et al. The global burden of rheumatoid arthritis: estimates from the global burden of disease 2010 study. Ann Rheum Dis 2014;73:1316-22. http://dx.doi.org/10.1136/ annrheumdis-2013-204627

2. Australian Institute of Health and Welfare. Rheumatoid arthritis. Canberra: AlHW; 2016. www.aihw.gov.au/rheumatoid-arthritis [cited 2017 Mar 1]

3. Smolen JS, Aletaha D, Koeller M, Weisman MH, Emery P. New therapies for treatment of rheumatoid arthritis. Lancet 2007;370:1861-74. http://dx.doi.org/ 10.1016/S0140-6736(07)60784-3

4. Solomon DH, Goodson NJ, Katz JN, Weinblatt ME, Avorn J, Setoguchi S, et al. Patterns of cardiovascular risk in rheumatoid arthritis. Ann Rheum Dis 2006;65:1608-12. http://dx.doi.org/10.1136/ard.2005.050377

5. Westlake SL, Colebatch AN, Baird J, Kiely P, Quinn M, Choy E, et al. The effect of methotrexate on cardiovascular disease in patients with rheumatoid arthritis: a systematic literature review. Rheumatology (Oxford) 2010;49:295-307. http://dx.doi.org/10.1093/rheumatology/kep366

6. Smolen JS, van der Heijde D, Machold KP, Aletaha D, Landewé R. Proposal for a new nomenclature of disease-modifying antirheumatic drugs. Ann Rheum Dis 2014:73:3-5. http://dx.doi.org/10.1136/annrheumdis-2013-204317

7. Kirwan JR, Bijlsma JW, Boers M, Shea BJ. Effects of glucocorticoids on radiological progression in rheumatoid arthritis. Cochrane Database Syst Rev 2007;1:CD006356. http://dx.doi.org/10.1002/14651858.CD006356

8. Wolfe F, Hawley DJ. Remission in rheumatoid arthritis. J Rheumatol 1985;12:245-52.

9. Nell VP, Machold KP, Eberl G, Stamm TA, Uffmann M, Smolen JS. Benefit of very early referral and very early therapy with disease-modifying antirheumatic drugs in patients with early rheumatoid arthritis. Rheumatology (Oxford) 2004;43:906-14. http://dx.doi.org/10.1093/rheumatology/keh199

10. van der Heijde DM, van Leeuwen MA, van Riel PL, van de Putte LB. Radiographic progression on radiographs of hands and feet during the first 3 years of rheumatoid arthritis measured according to Sharp's method (van der Heijde modification). J Rheumatol 1995;22:1792-6.

11. van der Linden MP, le Cessie S, Raza K, van der Woude D, Knevel R, Huizinga TW, et al. Long-term impact of delay in assessment of patients with early arthritis. Arthritis Rheum 2010;62:3537-46. http://dx.doi.org/10.1002/ art. 27692

12. Lopez-Olivo MA, Siddhanamatha HR, Shea B, Tugwell P, Wells GA, Suarez-Almazor ME. Methotrexate for treating rheumatoid arthritis. Cochrane Database Syst Rev 2014;6:CD000957. http://dx.doi.org/10.1002/ 14651858.CD000957.pub2

13. Hazlewood GS, Barnabe C, Tomlinson G, Marshall D, Devoe D, Bombardier C. Methotrexate monotherapy and methotrexate combination therapy with traditional and biologic disease modifying antirheumatic drugs for rheumatoid arthritis: abridged Cochrane systematic review and network meta-analysis. BMJ 2016;353:i1777. http://dx.doi.org/10.1136/bmj.i1777

14. Donahue KE, Gartlehner G, Jonas DE, Lux LJ, Thieda P, Jonas BL, et al. Systematic review: comparative effectiveness and harms of disease-modifying medications for rheumatoid arthritis. Ann Intern Med 2008;148:124-34. http://dx.doi.org/10.7326/0003-4819-148-2-200801150-00192

15. Singh JA, Saag KG, Bridges SL Jr, Akl EA, Bannuru RR, Sullivan MC, et al. 2015 American College of Rheumatology guideline for the treatment of rheumatoid arthritis. Arthritis Rheumatol 2016;68:1-26. http://dx.doi.org/10.1002/art.39480

16. Smolen J, Landewé R, Breedveld FC, Buch M, Burmester G, Dougados M, et al. EULAR recommendations for the management of rheumatoid arthritis with synthetic and biological disease-modifying antirheumatic drugs: 2013 update. Ann Rheum Dis 2014;73:492-509. http://dx.doi.org/10.1136/ annrheumdis-2013-204573

17. Ngian GS, Briggs AM, Ackerman IN, Van Doornum S. Management of pregnancy in women with rheumatoid arthritis. Med J Aust 2016;204:62-3. http://dx.doi.org/10.5694/mja15.00365

18. Kavanaugh A, Cush JJ, Ahmed MS, Bermas BL, Chakravarty E, Chambers C et al. Proceedings from the American College of Rheumatology Reproductive Health Summit: the management of fertility, pregnancy, and lactation in women with autoimmune and systemic inflammatory diseases. Arthritis Care Res (Hoboken) 2015;67:313-25. http://dx.doi.org/10.1002/ acr.22516
19. Shea B, Swinden MV, Tanjong Ghogomu E, Ortiz Z, Katchamart W, Rader T, et al. Folic acid and folinic acid for reducing side effects in patients receiving methotrexate for rheumatoid arthritis. Cochrane Database Syst Rev 2013;5:CD000951. http://dx.doi.org/10.1002/14651858.CD000951.pub2

20. Marmor MF, Kellner U, Lai TY, Lyons JS, Mieler WF; American Academy of Ophthalmology. Revised recommendations on screening for chloroquine and hydroxychloroquine retinopathy. Ophthalmology 2011;118:415-22. http://dx.doi.org/10.1016/j.ophtha.2010.11.017

21. Anaphylaxis: emergency management for health professionals [wallchart] Aust Prescr 2011;34:124. http://dx.doi.org/10.18773/austprescr.2011.066

22. Hsu D, Katelaris C. Long-term management of patients taking immunosuppressive drugs. Aust Prescr 2009;32:68-71. http://dx.doi.org/ 10.18773/austprescr.2009.035

23. Lu T, Hill C. Managing patients taking tumour necrosis factor inhibitors. Aust Prescr 2006;29:67-70. http://dx.doi.org/10.18773/austprescr.2006.042

24. McColl G. Tumour necrosis factor alpha inhibitors for the treatment of adult rheumatoid arthritis. Aust Prescr 2004;27:43-6. http://dx.doi.org/10.18773/ austprescr.2004.038

25. Lee A, Pile K. Disease modifying drugs in rheumatoid arthritis. Aust Prescr 2003;26:36-40. http://dx.doi.org/10.18773/austprescr.2003.028

26. Shankaranarayana $S$, Barrett $C$, Kubler $P$. The safety of leflunomide. Aust Prescr 2013;36:28-32. http://dx.doi.org/10.18773/austprescr.2013.010

27. Randall KL. Rituximab in autoimmune diseases. Aust Prescr 2016:39:131-4. http://dx.doi.org/10.18773/austprescr.2016.053

28. McLean-Tooke A, Aldridge C, Waugh S, Spickett GP, Kay L. Methotrexate, rheumatoid arthritis and infection risk: what is the evidence? Rheumatology (Oxford) 2009;48:867-71. http://dx.doi.org/10.1093/rheumatology/kep101

29. Galloway JB, Hyrich KL, Mercer LK, Dixon WG, Fu B, Ustianowski AP, et al.; BSRBR Control Centre Consortium; British Society for Rheumatology Biologics Register. Anti-TNF therapy is associated with an increased risk of serious infections in patients with rheumatoid arthritis especially in the first 6 months of treatment: updated results from the British Society for Rheumatology Biologics Register with special emphasis on risks in the elderly. Rheumatology (Oxford) 2011;50:124-31. http://dx.doi.org/10.1093/ rheumatology/keq242

30. Kourbeti IS, Ziakas PD, Mylonakis E. Biologic therapies in rheumatoid arthritis and the risk of opportunistic infections: a meta-analysis. Clin Infect Dis 2014;58:1649-57. http://dx.doi.org/10.1093/cid/ciu185

31. Lahiri M, Dixon WG. Risk of infection with biologic antirheumatic therapies in patients with rheumatoid arthritis. Best Pract Res Clin Rheumatol 2015;29:290-305. http://dx.doi.org/10.1016/j.berh.2015.05.009

32. Bykerk VP, Bingham CO, Choy EH, Lin D, Alten R, Christensen R, et al. Identifying flares in rheumatoid arthritis: reliability and construct validation of the OMERACT RA Flare Core Domain Set. RMD Open 2016;2:e000225. http://dx.doi.org/10.1136/rmdopen-2015-000225

33. Markusse IM, Dirven L, Gerards AH, van Groenendael JH, Ronday HK, Kerstens PJ, et al. Disease flares in rheumatoid arthritis are associated with joint damage progression and disability: 10-year results from the BeSt study. Arthritis Res Ther 2015;17:232. http://dx.doi.org/10.1186/s13075-015-0730-2

34. Whittle SL, Richards BL, Husni E, Buchbinder R. Opioid therapy for treating rheumatoid arthritis pain. Cochrane Database Syst Rev 2011;11:CD003113. http://dx.doi.org/10.1002/14651858.CD003113.pub3

35. Department of Health. The Australian Immunisation handbook. 10th ed. Canberra: Australian Government; 2015.

36. Goldberg RJ, Katz J. A meta-analysis of the analgesic effects of omega-3 polyunsaturated fatty acid supplementation for inflammatory joint pain. Pain 2007;129:210-23. http://dx.doi.org/10.1016/j.pain.2007.01.020

37. Cameron M, Gagnier JJ, Chrubasik S. Herbal therapy for treating rheumatoid arthritis. Cochrane Database Syst Rev 2011;2:CD002948. http://dx.doi.org/ 10.1002/14651858.CD002948.pub2

38. Therapeutic Goods Administration. Regulation of biosimilar medications Version 2.0, December 2015. Canberra: Department of Health. www.tga.gov.au/ publication/evaluation-biosimilars [cited 2017 Mar 1] 